\title{
Study of changes in the blood levels of copper and zinc following the blood exchange transfusion in neonates with hyperbilirubinemia
}

\section{Mehrdad Mirzarahimi, Afsaneh Enteshari-Moghaddam*, Raheleh Asghari Moghaddam, Abbas Naghizade, Mohammad Mazani}

Faculty of Medicine, Ardabil University of Medical Science, Ardabil, Iran

Received: 05 May 2016

Accepted: 08 June 2016

\section{*Correspondence:}

Dr. Afsaneh Enteshari-Moghaddam

E-mail: afsanehenteshary@gmail.com

Copyright: ( $)$ the author(s), publisher and licensee Medip Academy. This is an open-access article distributed under the terms of the Creative Commons Attribution Non-Commercial License, which permits unrestricted non-commercial use, distribution, and reproduction in any medium, provided the original work is properly cited.

\section{ABSTRACT}

Background: Blood exchange transfusion (EXT) is an essential treatment method in some icteric newborns and causes some changes in trace elements in them. The effects of blood exchange transfusion on zinc ( $\mathrm{Zn}$ ) and copper $\mathrm{Cu}$ in newborn infants is unknown. This study was conducted to determine the possible effects of EXT on $\mathrm{Zn}$ and $\mathrm{Cu}$ by comparing the levels of $\mathrm{Zn}$ and $\mathrm{Cu}$ in jaundiced neonates.

Methods: In this study, 30 jaundiced term neonates undergoing EXT for the first time, because of idiopathic unconjugated hyperbilirubinemia, were selected. The $\mathrm{Zn}$ and $\mathrm{Cu}$ levels of 30 blood bank donors' samples used for EXT were measured and 30 pairs of umbilical cord blood samples were examined for $\mathrm{Zn}$ and $\mathrm{Cu}$ before and one hour and five days after exchange transfusion. The serum bilirubin concentration was measured before and after EXT. The collected data in laboratory were analysed by statistical methods using SPSS.19.

Results: In this study $43 \%$ were girls and $56.7 \%$ were boys and the average age of the infants was 4.56 days at the time of admission. Before EXT, the average of serum bilirubin was $27.74 \pm 2.03 \mathrm{mg} / \mathrm{dl}$, and the average of serum $\mathrm{Zn}$ was $48.53 \pm 4.94 \mu \mathrm{g} / \mathrm{dl}$ that was lower than serum $\mathrm{Zn}$ concentration one hour after EXT $(55.98 \pm 7.60 \mu \mathrm{g} / \mathrm{dl})$ and five days after EXT $(56.63 \pm 10.92 \mu \mathrm{g} / \mathrm{dl})$. This difference was statistically significant $(\mathrm{P}=0.001)$. Furthermore, the average of serum $\mathrm{Cu}$ concentration was $59.56 \pm 10.92 \mu \mathrm{g} / \mathrm{dl}$ before EXT, $60.48 \pm 10.05 \mu \mathrm{g} / \mathrm{dl}$ after EXT and $58.64 \pm 8.06 \mu \mathrm{g} / \mathrm{dl}$ five days after EXT that didn't vary significantly from each other.

Conclusions: The results showed that after EXT, the serum Zn concentration was higher than before EXT but the changes in serum $\mathrm{Cu}$ concentration was little and negligible.

Keywords: Trace elements, Exchange transfusion, Icteric newborn, Zinc, Copper, Hyperbilirubinemia

\section{INTRODUCTION}

Jaundice or hyperbilirubinemia in neonates means the yellow discoloration of the skin or mucosa. Clinical jaundice in newborns is visible when the serum bilirubin level is above 5 milligrams per deciliter. ${ }^{1}$ Exchange transfusion (EXT) is replacement of all or the majority of the mass of red blood cells and blood plasma of a recipient, with one or some compatible donors' plasma and red blood cells. Hemolytic disease and hyperbilirubinemia in neonates are the main indications of EXT. Newborns with jaundice will undergo blood replacement if the intensive phototherapy doesn't return the serum bilirubin level to a safe level and if the risk of developing kernicterus is higher than the risk of this treatment or a child has the symptoms of kernicterus. In case that one needs to reduce blood hematocrit (polycythemia), or in case of severe anemia, relative EXT can be used. This treatment method should be repeated as many times as it is required, so that the indirect serum 
bilirubin level would reach to an acceptable level. ${ }^{1,2}$ Blood transfusion complications include increased use of heparin, graft- versus- host disease, hemolysis, hyperkalemia, hyponatremia, arrhythmias, hypoglycemia, hypocalcaemia, tetany, thrombocytopenia and infections associated with blood transfusions, cardiac arrhythmias, embolism, necrotizing enterocolitis and thrombosis, accidental bleeding, air embolism, hemolysis caused by mechanical or thermal damage, hypothermia, intracranial hemorrhage, intracranial pressure fluctuations and fluctuations in systemic blood pressure due to hypovolemia or hypervolemia. ${ }^{3,4}$ Mortality after EXT in neonates has been reported, 5.3 per 1000 patients and 3 cases per 1000 EXT. $^{5,6}$

Zinc is an essential element in human nutrition with a wide range of biological functions. It also has a critical role in physical growth of digestive and immune systems. Zn deficiency in infants and children can cause stunted growth, increased incidence of infections (pneumonia, gastroenteritis) and neurobehavioral change. Studies on the $\mathrm{Zn}$ benefits have shown that the $\mathrm{Zn}$ compounds can reduce the risk of developing pneumonia and gastroenteritis. In general, $\mathrm{Zn}$ strengthens the immune system and increases the body's immunity as well as decreasing the infection rate. .,6 $^{5,}$

Copper is a strong antioxidant that destroys the free radicals and prevents cellular damage. $\mathrm{Cu}$ has a lot of functions in the body, including glucose oxidation resulting in the release of energy in the body, helping body to absorb iron, supplying oxygen to body tissues, including brain, helping the thyroid gland to balance hormone secretion, and being part of an essential enzyme for the synthesis of adrenaline and etc. ${ }^{7,8} \mathrm{Zn}$ and $\mathrm{Cu}$ are necessary and desirable elements for the growth and development of infants. ${ }^{9}$

Studies have shown that blood transfusions leads to a reduction in infants serum antioxidant capacity and changes in the serum microelements. ${ }^{10,11}$ Change in the serum levels of $\mathrm{Cu}$ and $\mathrm{Zn}$ has not been established in infants with exchange transfusion; thereupon, the present study intends to investigate the changes in two serum microelements in jaundiced infants undergoing exchange transfusion.

\section{METHODS}

This study was descriptive-analytical. Measurement of the levels of serum selenium, $\mathrm{Zn}$ and $\mathrm{Cu}$ was performed on infants at three times (before EXT, an hour after EXT, and five days after the EXT), as well as on blood bags used for newborns.

This study was conducted on 30 full-term newborns with hyperbilirubinemia and having indication of EXT (serum bilirubin greater than 25), who had been hospitalized in the neonatal ward for six months. After centrifugation, the blood serum was separated and the serum levels of $\mathrm{Cu}$ and $\mathrm{Zn}$ were measured in the laboratory. The measurement of serum levels of $\mathrm{Zn}$ and $\mathrm{Cu}$ was carried out in the plastic containers not to be contaminated by trace elements. The samples were collected in plastic tubes after centrifugation. Subsequently, the obtained sera were stored in a freezer at $-20{ }^{\circ} \mathrm{C}$. The level of salt in samples was measured after collecting all the samples. The exclusion criteria in this study were being a pre-term infant, birth accidents, birth trauma, asphyxia, congenital malformation, sepsis, taking medicine by mother, mothers' smoking or substance abuse, maternal morbidity, and consumption of dried milk. The parental consent for including the infant in the study was obtained before EXT. Collected data analyzed using statistical methods in SPSS.19.

\section{Measurement of the zinc}

The serum zinc measurement was performed by Zink quantification kit of Biochemistry Company through spectrophotometry, in which, the serum $\mathrm{Zn}$ created a complex with 5-Br-PAPS, a colorimetric reagent, which was maximally absorb measured at the wavelength of 578 $\mathrm{nm}$.

In this procedure, $50 \mu \mathrm{l}$ serum sample or calibrator was mixed with $1000 \mu$ l reagent and was incubated at $37{ }^{\circ} \mathrm{C}$ for 10 minutes. Then, the absorbance against the blank was measured at a wavelength of 578 and the serum values were calculated.

\section{Measurement of $\mathrm{Cu}$}

The serum $\mathrm{Cu}$ measurement was performed by Zink quantification kit of Biochemistry Company through spectrophotometry, in which, the serum $\mathrm{Cu}$ formed a complex with (3.5-dibromo-2-pyridylazo) -N-ethylinsulopropylaniline, a colorimetric reagent, and was maximally absorbed at the wavelength of $578 \mathrm{~nm}$.

In measuring serum $\mathrm{Cu}, 50 \mu \mathrm{l}$ serum sample or calibrator was mixed with $1000 \mu \mathrm{l}$ reagent and incubated at $37^{\circ} \mathrm{C}$ for 10 minutes. Then, the absorbance was measured against the blank at a wavelength of 578 and the serum values were calculated.

\section{RESULTS}

Of infants, $13(43.3 \%)$ were female and $17(56.7 \%)$ were male. The average age of the infants at the time of admission was 4.56 days. Of all infants, $6(20 \%)$ had been born through cesarean section and $24(80 \%)$ by vaginal delivery. Average birth weight in the female and male newborns was 3253.84 gr and $3082.35 \mathrm{gr}$, respectively. $16(53.3 \%)$ had jaundice on the second day after birth. The majority of the infants with 12 patients (40\%) had blood group A. There was a significant difference between serum $\mathrm{Zn}$ level in neonates' blood in baseline and an hour and five days after EXT $(\mathrm{P}=0.001)$ (Table 1). 
There was no significant difference between levels of serum $\mathrm{Cu}$ in neonates before EXT and one hour and five days after EXTs. There was statistically significant difference between the level of direct bilirubin in neonates' blood serum before EXT and an hour and five days after $\operatorname{EXT}(\mathrm{p}=0.001)$.

Table 1: Comparison of serum Zink levels of the infants before and an hour and five days after EXT.

\begin{tabular}{|llll|}
\hline Variable name & $\begin{array}{l}\text { Before EXT } \\
(\text { Mean } \pm \text { SD) }\end{array}$ & $\begin{array}{l}\text { An hour after EXT } \\
(\text { Mean } \pm \text { SD) }\end{array}$ & $\begin{array}{l}\text { Five days after EXT } \\
\text { (Mean } \pm \text { SD) }\end{array}$ \\
\hline Zink $(\mathbf{Z n )}$ & $48.53 \pm 4.94$ & $55.98 \pm 7.60 *$ & $55.63 \pm 6.17 *$ \\
\hline Cu & $59.6 \pm 10.9$ & $60.5 \pm 10.1$ & $60.7 \pm 9.8$ \\
\hline Direct bilirubin & $1.01 \pm 0.34$ & $0.69 \pm 0.14 *$ & $0.61 \pm 0.14 *$ \\
\hline
\end{tabular}

$* \mathrm{P}<0.05$ compared with before EXT, * $\mathrm{P}<0.05$ compared with an hour after EXT

The mean levels of serum $\mathrm{Zn}$ and $\mathrm{Cu}$ before EXT and an hour and five days after EXTs didn't have any significant difference between male and female neonates.

The mean serum $\mathrm{Zn}$ and $\mathrm{Cu}$ levels before EXT and an hour and 5 days after EXT didn't have any significant difference between blood types.

\section{DISCUSSION}

In this study, $\mathrm{Zn}$ and $\mathrm{Cu}$ levels in the blood serum were measured and a significant change was observed in the serum $\mathrm{Zn}$ and $\mathrm{Cu}$ levels before EXT and one hour and 5 days after EXT. Gillian et al in a study measured levels of copper and $\mathrm{Zn}$ after blood transfusion and found an increase in level of $\mathrm{Zn}$ and no change in the $\mathrm{Cu}$ level. ${ }^{12} \mathrm{In}$ a study by Wilson et al, the levels of selenium, manganese and glutathione peroxidase after EXTs were investigated, the results showed an increase in serum levels of manganese and glutathione peroxidase. ${ }^{13}$

The study by Lindeman et al was conducted to evaluate the change in the concentration level of peroxide and antioxidants in plasma following the EXT. Results showed that a change in the concentration of peroxide and antioxidants and an increase in the formation of free radicals in infants after EXT. ${ }^{14}$

Khatami and et al in a study assessed the serum levels of Iron $(\mathrm{Fe})$ and $\mathrm{Zn}$ after EXT and observed an increase in serum $\mathrm{Fe}$ and $\mathrm{Zn}$ levels following EXT. ${ }^{15}$ Khoshdel et al in a study measured glucose and calcium after EXT and revealed a reduction in calcium level and no change in glucose level following EXT. ${ }^{11}$ In the study by Khatami and Parvaresh, a change was reported in the serum selenium level after EXT in infants. ${ }^{16}$

The present study confirmed the findings of other recent studies that have reported the reduction of serum $\mathrm{Zn}$ level in icteric infants, when the serum bilirubin increased more likely due to competitive effect. ${ }^{17,18}$
In this study the mean serum $\mathrm{Zn}$ level in newborns at admission (before EXT) was $48.53 \pm 4.94 \mu \mathrm{g} / \mathrm{dl}$ that was at a level lower than normal range in healthy newborns (50$100 \mu \mathrm{g} / \mathrm{dl})$.

In this study, the mean serum $\mathrm{Zn}$ level in icteric neonates was $56 \pm 7.6 \mu \mathrm{g} / \mathrm{dl}$ after EXT, which was significantly different from the serum Zink level before it, with an increase of about $8 \%$ compared to its level before the EXT.

The study also showed that the mean serum $\mathrm{Zn}$ level in the blood bank donors was $91.7 \pm 11.5 \mu \mathrm{g} / \mathrm{dl}$, which belongs to the adults' normal range. This mean was greater in comparison to the mean serum $\mathrm{Zn}$ level in the infants. It appears that concerning the relative deficit of zink in the neonates under study, the blood bank donors' serum $\mathrm{Zn}$ level was likely to be reason for the increase in serum Zn level after EXT. Put it another way, EXT can be considered as a contributing factor in changing the serum $\mathrm{Zn}$ level.

Gillian et al. in a study reported a rise in the serum $\mathrm{Zn}$ level three days after blood EXT. ${ }^{12}$ In the study undertaken by Khatami et al. serum Zn level had an increase after EXT compared to its level before EXT. ${ }^{15}$

The results of this study showed that five days after EXT, the mean serum $\mathrm{Zn}$ level was $56.6 \pm 6.2 \mu \mathrm{g} / \mathrm{dl}$ that indicated a significant difference between the serum $\mathrm{Zn}$ levels of the infants before EXT and five days following EXT. But, there was no significant difference between the serum $\mathrm{Zn}$ levels an hour after EXT and five days following it.

Also, results showed that there was no significant difference in serum $\mathrm{Zn}$ level before EXT, one hour, and five days after EXT between two sexes.

Also, in this study no significant relationship was found between the weight of the infants and the Zink concentration before, an hour and five days after EXT. In this study, there wasn't any significant relationship 
between the serum bilirubin and $\mathrm{Zn}$ before and after EXT.

In this study, the average serum levels of $\mathrm{Cu}$ before EXT was $59.6 \pm 10.9 \mu \mathrm{g} / \mathrm{dl}$ that was in the normal range. The average serum levels of $\mathrm{Cu}$ after EXT was $60.5 \pm 10.1$ $\mu \mathrm{g} / \mathrm{dl}$, that didn't vary significantly from before EXT.

This study indicated that the serum levels of $\mathrm{Cu}$ in the blood donors were $90.9 \pm 17.5 \mu \mathrm{g} / \mathrm{dl}$ which was in the adults' normal range.

The highest level of $\mathrm{Cu}$ accumulation occur in the liver of the foetus in the third trimester of pregnancy, so premature infants compared to term infants have lower $\mathrm{Cu}$ levels. ${ }^{6,19}$ It seems that in cases with increasing serum bilirubin and albumin decrease due to slight $\mathrm{Cu}$ binding to albumin has not much impact on reducing serum levels of $\mathrm{Cu}$. Some other studies also have suggested this point. In this study, the mean serum level of $\mathrm{Cu}$ in the newborns (icteric) was $59.6 \pm 10.9 \mu \mathrm{g} / \mathrm{dl}$ that was of the healthy infants' normal range $(30-70 \mu \mathrm{g} / \mathrm{dl})$. In general, it seems appears that adult plasma transfusion with high concentration of $\mathrm{Cu}$ and higher ceruloplasmin will increase serum levels of $\mathrm{Cu}$. In this study, no significant difference was seen in the serum levels of $\mathrm{Cu}$ after EXT compared to before EXT. According to the mean serum levels of the infants and the blood donors in this study, it seems that the lack of change can be due to similar level of $\mathrm{Cu}$ in infants and the donors.

In the Gillian et al., study, the serum levels of $\mathrm{Cu}$ before and after EXT were not significantly different. ${ }^{12}$

The results of this study showed that the mean serum cu level five days after EXT was 58.6 $\pm 8.1 \mu \mathrm{g} / \mathrm{dl}$. There was no significant difference between the serum cu level of infants before EXT and five days following EXT. Although, the level of serum cu five days following exchange transfusion had slight decline in comparison to an hour after EXT but this difference was negligible which this slight difference can be due to condition of neonatal hospitalized in hospital, not receiving adequate breastfeeding, stress and receiving antibiotics.

\section{CONCLUSION}

Results showed that the serum $\mathrm{Zn}$ level one hour and 5 days after the EXT compared to before EXT have been increased change and these changes had no effect on serum levels of $\mathrm{Cu}$. According to the differences in the levels of these elements in the mother's blood serum, and their impact on the reserves in the embryonic period, and the primary serum levels of these elements in infants, maternal nutrition, breastfeeding, level of these elements in breast milk, age, gender of infants, duration of their hospitalization, serum levels of blood donors and etc., doing further studies is essential.
Funding: No funding sources

Conflict of interest: None declared

Ethical approval: The study was approved by the institutional ethics committee

\section{REFERENCES}

1. Wong R, Desander G, Sibley E. Neonatal jaundice and liver disease. Fanaroff and Martin's Neonatal prenatal Medicine: Disease of the fetus and infant, 8th ed. St Louis: Mosby; 2006: 1446-1450.

2. Behrman RE, Kliegman RM. Nelson essential of pediatrics. 6th ed. Philadelphia: W.B. Saunders; 2011: 334-337.

3. Behrman RE, Kliegman RM, Jenson HB. Nelson textbook of pediatrics. 19th ed. Philadelphia: W.B. Saunders; 2011: 603-612.

4. Steiner LA, Bizzarro MJ, Ehrenkranz RA, Gallagher PG. A decline in the frequency of neonatal exchange transfusions and its effect on exchangerelated morbidity and mortality. Am J Dis Child. 2007;120(1):127-32.

5. Roohani N, Hurrell R, Kelishadi R, Schulin R. Zinc and its importance for human health. J Res Med Sci. 2013;18(2):144-57.

6. Walravens PA. Nutritional Importance of Copper and Zinc in Neonates and Infants. Clin Chem J. 1980;26(2):185-9.

7. Robinson C, Weigley E, Mueller D. Robinson's Basic Nutrition and Diet Therapy. 8th Edition, New Jersey, Prentice-Hall Inc; 1997: 201-230.

8. Keen CL, Uriu-Hare J, Hawk S, Jankowski M, Daston G, Kwik-Uribe C. Effect of Copper Deficiency on Prenatal Development and Pregnancy Outcome. Am J Clin Nutr. 1998;67(5):1003-11.

9. Sakha K, Ostad Rahimi R, Jafari Rohi A, Abasalizadeh SH. Comparison of serum zinc and copper levels between term and preterm neonates cord blood and their mothers' blood. Iran J Pediatr. 2005;15:255-60.

10. Lockitch G, William J Godolphin WJ, Pendray MR, Quigley G. The effect of red cell and plasma transfusion on serum zinc and copper levels in the neonate. Am J Clin Nutr. 1983;38:701-5.

11. khoshdel A, danesh A. Changes of blood sugar and total calcium in hyperbilirubinemic neonates after exchange transfusion. J Shahrekord Univ Med Sci. 2003;5(3):35-40.

12. Gillian L, William J, Margaret R, Gayle T. The effect of red cell and plasma transfusion on serum zinc and copper levels in the neonate. Am J Clin Nutr. 1993;62:701-5.

13. Wilson DC, Tubman RJ, Bell N, Halliday HL, McMaster D. Effect of Blood Transfusion on Plasma Selenium, Glutathione Peroxidase and Manganese Levels in Very Low Birth Weight Infants. J Clin Biochem Nutr. 1999;60:126-32.

14. Lindeman JH, Lentjes EG, Houd kamp E, Van zoeren-Groben D, Schrijver J, Berger HM, Effect of 
exchange transfusion on plasma antioxidants in the newborn. N Engl J Med. 1992;90:200-3.

15. Khatami SF, Parvaresh P, Shakerian-Ardekani Th, Gharib M. Comparing micronutrients concentration before and after blood exchange transfusion in newborns. Iran J Pediatr. 2007;17:118-25.

16. Khatami F, Parvaresh P, Parvaresh P, Gharib M. The Investigation of Effects of Blood Exchange Transfusion on Selenium in Newborn Infants. Iran J Pediatr. 2013;23(2):131-7.

17. Hasant EJ. Evaluation of Copper, Zinc, Manganese, and Magnesium Levels in Newborn Jaundice. India J Pediatr. 2011;58:163-9.

18. Boskabadi H, Maamouroi Gh, Mohsen Zade H, Shakeri MT, Ghayour M. Comparison of Zinc Level between Neonates with Jaundice and Healthy Neonates. Int J Pediatr. 2014;2:34.

19. Rihab M, Hamdan Z, Elhassan M, Sumia. Zinc and copper levels in low birth weight deliveries in Medani Hospital, Sudan. J Trop Pediatr Nutr. 2014;7:386-9.

Cite this article as: Mirzarahimi M, EnteshariMoghaddam A, Moghaddam RA, Naghizade A, Mazani M. Study of changes in the blood levels of copper and zinc following the blood exchange transfusion in neonates with hyperbilirubinemia. Int J Sci Rep 2016;2(7):138-42. 